\title{
Mediterranean river biomonitoring in Central Italy: Diatom biodiversity and characterization of communities
}

\author{
Valentina DELLA BELLA, ${ }^{1 *}$ Rosalba PADULA,${ }^{2}$ Fedra CHARAVGIS, ${ }^{2}$ Alessandra CINGOLANI, ${ }^{2}$ Paolo COLANGELO \\ ${ }^{1}$ ARPA UMBRIA, Environmental Protection Agency of Umbria Region, Via C.A. Dalla Chiesa 32, 05100, Terni; ${ }^{2}$ ARPA UMBRIA, \\ Environmental Protection Agency of Umbria Region, Via Pievaiola 207/B-3, 06132, Perugia; ${ }^{3}$ CNR-ISE, Institute of Ecosystems \\ Study, Largo V. Tonolli 50, 28922 Verbania-Pallanza, Italy \\ *Corresponding author: v.dellabella@arpa.umbria.it
}

\begin{abstract}
In compliance with the European and Italian regulations, the Environmental Protection Agency of Umbria Region (ARPA Umbria) defined specific river monitoring programs and networks based on river type definition, human pressures and risk analysis. The Umbria Region lies in Central Italy and it can be split into three hydro-ecoregions belonging to the Mediterranean area. Data on diatom community composition were collected in five different Mediterranean macrotypes (M1-M5) throughout the diatombased river monitoring network that is composed by 52 sampling stations in 36 watercourses. The main aim of this study was to characterise and to analyse diatom diversity across the different regional river macrotypes. Specifically, we investigated if: i) there were differences in species diversity (species richness and Shannon Index) among macrotypes; ii) there was difference in three water quality indexes (ICMi, IPS, and TI) among sites; and iii) there was a relationship between the observed ICMi, IPS and TI value and the diatom diversity. Two-hundred diatom species and varieties were identified, and the number of species per sampling

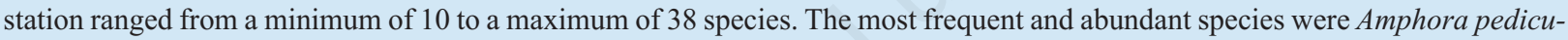
lus, Achnanthidium minutissimum, Navicula cryptotenella, Nitzschia dissipata, and each macrotype showed some peculiar species. The ecological status evaluation based on Intercalibration Common Metric Index (ICMi) classified 69\% of the water bodies in high or good class. Significant differences in diversity and ICMi value among stream macrotypes were found, with M4 (small and medium mountain) and M5 (small, lowland, temporary) typologies showing the lowest species richness, and with M5 showing the lowest Shannon Index. Conversely, M2 (small and medium lowland) and M5 showed the highest ICMi value. Lastly, significant correlations between Shannon Index and the ICMi, IPS and TI indexes were found.
\end{abstract}

Key word: Benthic algae; indicator species; Bacillariophyceae; diversity metrics; Water Framework Directive 2000/60/EC.

\section{INTRODUCTION}

Ecological status assessment based on benthic algal communities is one of the requirements of the European Water Framework Directive 2000/60/EC (WFD; European Commission, 2000), implemented in Italy with Legislative Decree 152/2006 (Italian Regulation, 2006). Diatoms are the algal group most widely used as indicators of river quality. They are the main component of phytobenthos of river water bodies and have biological and ecological characteristics that make them a good indicator for the characterization of water quality (Kelly et al., 1998). They have a cosmopolitan distribution and high sensitivity to water physico-chemical characteristics and environmental conditions (for a review see Prygiel et al., 1999).

In Italy, studies on diatom communities have been mainly focused on Alpine streams (Cantonati and Pipp, 2000; Battegazzore et al., 2004; Bona et al., 2007; Rott et al., 2006; Zorza and Honsell, 2008; Beltrami et al., 2009; Falasco et al., 2012) and some main watercourses in Southern Italy (Battegazzore et al., 2003; Finocchiaro et al., 2011). Existing data on benthic diatom assemblages of Mediterranean rivers of Central Italy are scattered, covering some central Apennine streams (Dell'Uomo, 1999; Scuri et al., 2006; Torrisi et al., 2008, 2010), some volcanic-siliceous streams (Della Bella et al., 2012), and the main river water body, the Tiber River (Cappelletti et al., 2005; Ciutti et al., 2007). A few studies on river diatom communities have been carried out on main streams of Umbria Region, Central Italy (Mancini et al., 2008).

In compliance with the European and national regulations, the Environmental Protection Agency of Umbria Region (ARPA Umbria) defined specific monitoring programs and networks based on river type definition, human pressures, and risk analysis (ARPA Umbria, 2008). ARPA Umbria accomplished the first biomonitoring of river diatoms between 2009 and 2012 and calculated the Intercalibration Common Metric Index (ICMi), developed in Italy for the assessment of benthic algal ecological status (Mancini and Sollazzo, 2009). The main purposes of this study were to analyse diatom diversity of regional river types and to identify the characterising diatoms of different river types in Umbria (Mediterranean river typologies defined by altitude, river basin area, and river hydrology). 
This study represented a contribution to diatom-based river quality assessment following the WFD in Italy and to evaluation of differences in diversity of diatom communities in Mediterranean river types. In detail, we investigated if: i) there were differences in species diversity (species richness and Shannon Index) among river types, ii) there was difference in ICMi, IPS, and TI value among sites, and iii) there was a relationship between the observed ICMi, IPS and TI value and the diatom diversity.

\section{METHODS}

\section{Study area}

The Umbria Region is located in the Mediterranean area of Central Italy and it is included in three hydroecoregions: Tuscan Hills, Apennines Centre and Italian Volcanics (Wasson et al., 2006; Italian Regulation, 2008; Fig. 1). The morphology varies from lowlands in the central area to highlands in the eastern part and it is mainly characterized by a temperate climate with hot, dry summers and cool, wet winters. Almost the entire area belongs to the Tiber River basin, in the hydrographic district of Central Italy. The Tiber River begins in the northern part of the Apennine Mountains and crosses the Umbria Region from North to South, collecting waters from several tributaries and with a length of $400 \mathrm{~km}$ before draining into the Tyrrhenian Sea in the Lazio Region. Tributaries from the eastern part of the region show steady flows due to carbonate sources from the
Apennines and a good ecological quality. On the contrary, all over the central and western area the rivers show a high flow variability and significant impacts on water quality, due to human activities.

According to national legislation (DM 131/08; Italian Regulation, 2008), 135 river waterbodies were included in the monitoring network and assigned to 19 types, which were grouped in five main Mediterranean macrotypes (M1-M5) defined in the European Intercalibration exercise (European Commission, 2008; Tab.1). Most of the regional water bodies belongs to macrotypes M5 (39\%) or M1 $(34 \%)$ and are characterized by small basins and low or temporary discharges, while there are few big rivers $(8 \%)$ with significant flows in floodplain areas (macrotype M3). Several rivers, altered by human activities such as land drainage, dredging, flood protection, water abstraction, building of dams to create reservoirs, have been designated as "artificial" (1; AWB) or "heavily modified" (20; HMWB) water bodies (Fig. 2).

In order to define monitoring networks and programs, a risk analysis and an anthropic pressure assessment have been carried out (ARPA Umbria, 2008). Data were collected using the diatom-based river monitoring network that is composed by 52 sampling stations distributed in 36 watercourses. Data were collected between 2009 and 2012. Almost 100 diatom samples were collected and analysed. Data gathered allowed to calculate for 48 out of 52 sites the Intercalibration Common Metric Index (ICMi), developed for the assessment of benthic algal ecological status follow-
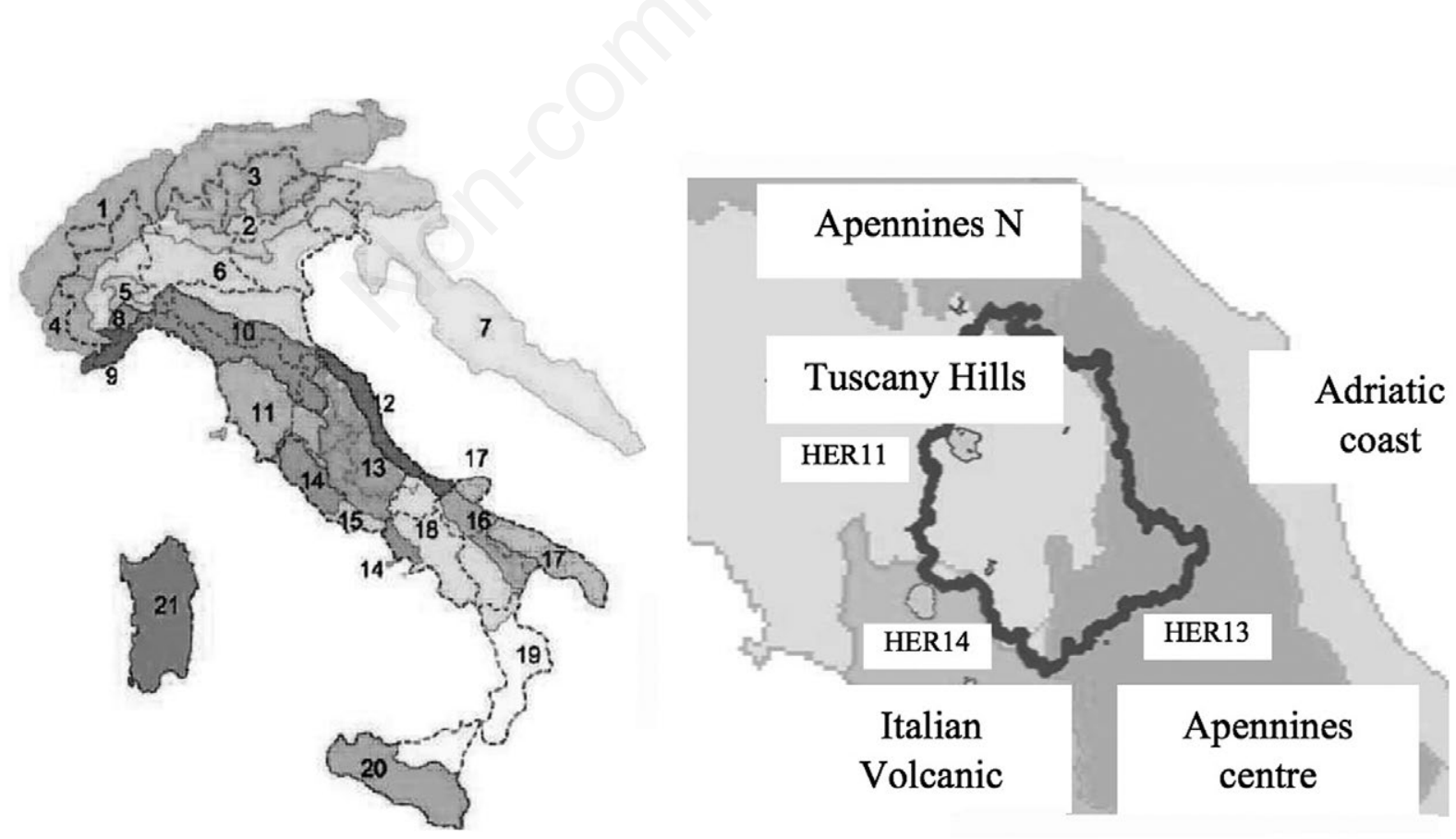

Fig. 1. Hydro-ecoregions (HER; WFD 2000/60/CEE) defined by CEMAGREF for Italy (Wasson et al., 2006), then verified at the local/regional scale and identified according to Basin Authority, Regions, Regional Environmental Agency and Italian Ministry of Environment (DM 131/08; Italian Regulation, 2008). HER11, Tuscany Hills; HER13, Apennine Centre; HER14, Italian volcanic regions. 
ing the formula: ICMi index $=($ RQE_IPS + RQE_TI $) / 2$ (Mancini and Sollazzo, 2009). The ICMi is based on two sub-indices: the IPS index (CEMAGREF, 1982), which mainly assesses the sensitivity of species to organic pollution and the TI Index (Rott et al., 1999), which is based on the species sensitivity to trophic pollution. For the diatombased ecological status assessment, the value of the two sub-indices have to be expressed as Ecological Quality Ratio (RQE_IPS and RQE_TI) with the respective refer- ence values for each river macrotype following the DM 260/2010 (Italian Regulation, 2010). Boundaries between quality classes adopted for river macrotypes M1-M2-M3M4 are: High/Good $=0.80$, Good/Moderate $=0.61$, Moderate $/$ Poor $=0.51$, Poor $/ \mathrm{Bad}=0.25$; and for $\mathrm{M} 5$ are: High $/$ Good $=0.88$, Good/Moderate $=0.65$, Moderate $/$ Poor $=0.55$, Poor $/ \mathrm{Bad}=0.26$ (reported values are the lowest value of higher class). We evaluated the ecological status on the basis ICMi for 38 out of 48 sites because ten sites

Tab. 1. River Mediterranean macrotypes identified in the Region Umbria.

\begin{tabular}{llc} 
River macrotype & River macrotype description & Number of water bodies \\
M1 & Small mid-altitude streams (200-800 m asl) & 45 \\
\hline M2 & Small and medium lowland streams $(<400 \mathrm{~m}$ asl) & 23 \\
\hline M3 & Large lowland rivers & 11 \\
\hline M4 & Small and medium mountain streams $(400-1500 \mathrm{~m}$ asl) & 10 \\
\hline M5 & Small, lowland, temporary $(<300 \mathrm{~m}$ asl $)$ & 2 \\
\hline
\end{tabular}

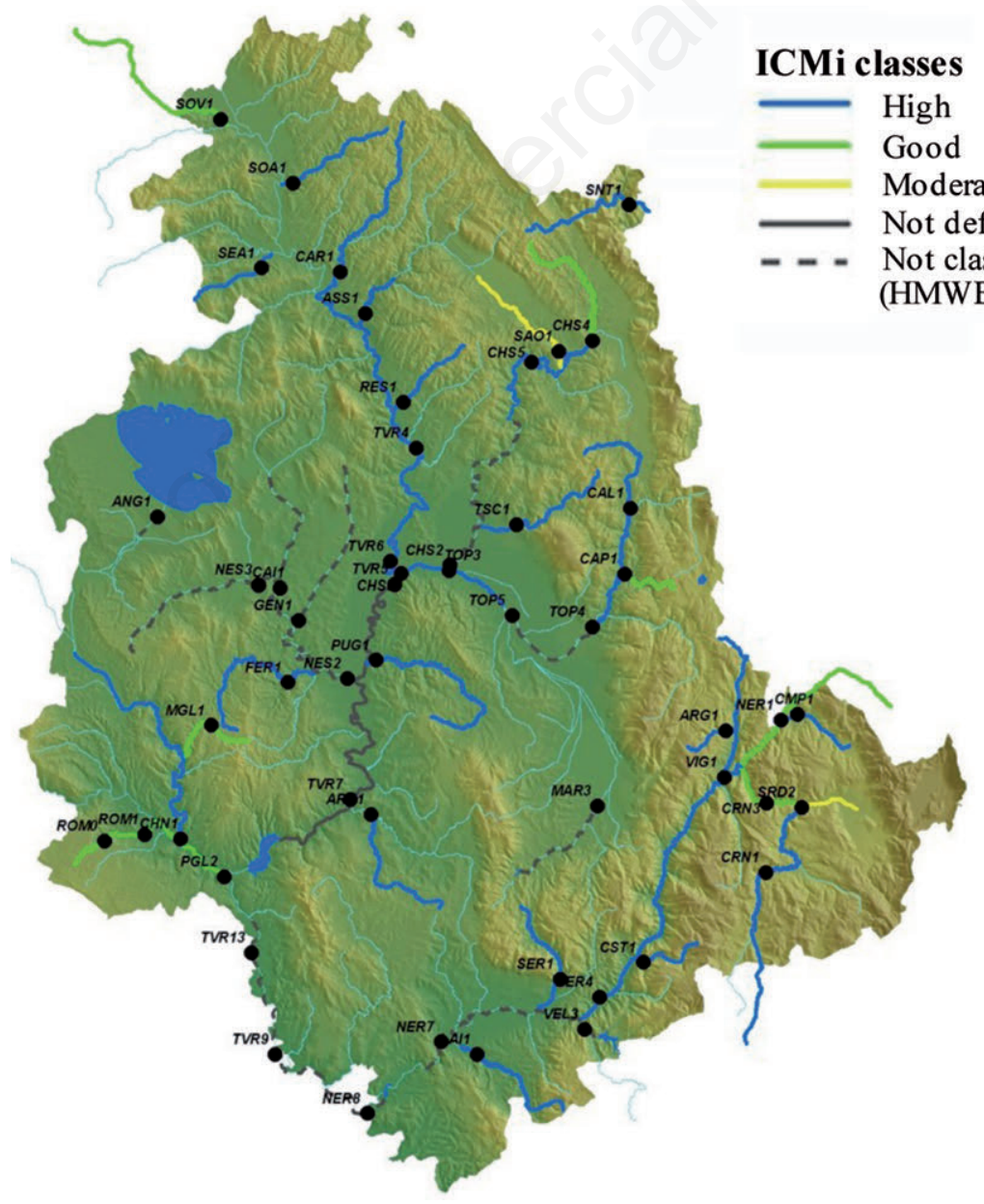

Fig. 2. Diatom-based river classification using ICMi Index. 
were defined as heavily modified/artificial water bodies (HMWB/AWB).

\section{Sampling activities, data analysis and statistics}

Diatom sampling, sample treatment and laboratory work were carried out according to the European recommendations (European Committee for Standardization, 2003, 2004) and national guidelines (APAT, 2007). In order to sample epilithic forms, the upper surface of five stones was brushed with a toothbrush in each sampling site. Diatom samples were immediately placed in an ice bag and carried to the laboratory. In order to identify the diatom frustules, the diatom valves were cleaned using hydrogen peroxide to eliminate organic matter and with hydrochloric acid to dissolve calcium carbonate. Clean diatom frustules were mounted in a synthetic resin with high-refraction index $\left(\mathrm{Naphrax}^{\circ}\right)$. Successively in each sample up to 400 valves were counted and classified at the species or the variety level using a light microscope with $1000 \mathrm{x}$ magnification. Morphometric measurements were made with the aid of image analysis software (CellB, Imaging Software for Life Sciences Microscopy ${ }^{\circ}$ OLYMPUS Soft Imaging Solutions $\mathrm{GmbH}$, Münster, Germany). The main references for diatom taxonomy were Krammer and Lange-Bertalot (1986, 1988, 1991a, 1991b, 2000), Krammer (2000), Lange-Bertalot (2001), and Hofmann et al. (2011).

In order to analyse diatom diversity and identify the characteristic species of different river macrotypes, we performed two types of statistical analyses. To define the characterizing species of river macrotypes, we applied the Indicator Species Analysis (ISA, Dufrene and Legendre, 1997). This analysis establishes indicator values for different species combining the information on relative abundances of species in a particular group of samples with the relative frequency of the species occurring in the group.
Successively, in order to test if there were differences in species diversity among macrotypes and hydro-geographic regions (HER), we used a GLM procedures including the diatom species richness or the Shannon Index as the response variables (assuming a Poisson distribution for species richness and a Gaussian for Shannon) and using in turn the macrotype (5 categories) and HER ( 2 categories) as independent variable. The diatom species richness and Shannon Index were calculated at site level. Successively, six separate GLMs were performed in order to test the presence of a significant difference among macrotypes and HERs for the three indexes ICMi, TI and IPS. Lastly, GLM was used in order to test if there are any significant relationship between ICMi, IPS and TI and diatom diversity (the observed species richness and Shannon at the site level). These analyses were also replicated excluding the 10 sites not classified because defined as heavily modified/artificial water bodies (HMWB/AWB). Significance of all GLMs was tested against a null model (i.e., no significant relationships with factors) by chi-squared test. All the statistical analyses were performed using the R statistical environment ver. 3.30 (R Core Team, 2015).

\section{RESULTS AND DISCUSSION}

A total of 200 diatom species and varieties were identified (Supplementary Tab. 1) in 96 collected samples (almost 41,000 counted frustules). The number of species per sample varied from 10 to 38 with a mean of 22 species. The most frequent and abundant species were Amphora pediculus (Kützing) Grunow, Achnanthidium minutissimum (Kützing) Czarnecki, Navicula cryptotenella Lange-Bertalot, Nitzschia dissipata (Kützing) Grunow ssp. dissipata (Tab. 2).

A. pediculus and A. minutissimum are cosmopolitan

Tab. 2. List of most frequent and abundant species. Only species found in more than $2 / 3$ of sampling sites are listed.

\begin{tabular}{|c|c|c|c|c|c|}
\hline Species & Sites & Samples & $\begin{array}{c}\text { Mean } \\
\text { relative } \\
\text { abundance } \\
(\%)\end{array}$ & $\begin{array}{c}\text { Median } \\
\text { relative } \\
\text { abundance } \\
(\%)\end{array}$ & $\begin{array}{c}\text { Max } \\
\text { relative } \\
\text { abundance } \\
(\%)\end{array}$ \\
\hline Amphora pediculus (Kützing) Grunow & 47 & 91 & 10.52 & 6.00 & 55.67 \\
\hline Achnanthidium minutissimum Kützing & 47 & 87 & 20.09 & 10.27 & 79.12 \\
\hline Navicula cryptotenella Lange-Bertalot & 45 & 79 & 4.53 & 2.10 & 23.90 \\
\hline Nitzschia dissipata (Kützing) Grunow & 45 & 72 & 2.58 & 0.67 & 25.24 \\
\hline Cocconeis placentula Ehrenberg & 42 & 64 & 8.84 & 0.85 & 86.82 \\
\hline Navicula tripunctata (Müller) Bory & 39 & 60 & 2.27 & 0.25 & 22.76 \\
\hline Gomphonema parvulum (Kützing) Kützing & 37 & 57 & 0.98 & 0.25 & 10.82 \\
\hline Gomphonema olivaceum (Hornemann) Brébisson & 40 & 54 & 1.65 & 0.25 & 19.01 \\
\hline Rhoicosphenia abbreviata (Ag.) Lange-Bertalot & 34 & 52 & 2.40 & 0.23 & 69.51 \\
\hline Nitzschia palea (Kützing) W. Smith & 35 & 47 & 2.14 & 0.00 & 21.13 \\
\hline
\end{tabular}


species, very common and abundant in the Italian rivers and streams, often dominant in diatom communities and considered pioneer species (Falasco and Bona, 2013). A. pediculus can tolerate high concentration of nutrients in water with low organic load, while A. minutissimum has a wide ecological range as it can tolerate large ranges of organic and inorganic pollution (Falasco et al., 2013). The high abundance and frequency of these both pioneer species were probably due to the high flow variability of rivers for the most part of the region in analysis. $N$. cryptotenella is also a cosmopolitan and mobile species. Like A. pediculus, this species is quite sensitive to organic pollution, and it can be found in oligotrophic to eutrophic waters (Falasco et al., 2013). N. dissipata, also found in several sampling sites though with less abundance, may become a dominant species in diatom community in site with medium - high content of nutrients such as nitrate and total phosphorus $\left(\mathrm{P}_{\text {tot }}>46.5 \mu \mathrm{g} \mathrm{L}^{-1}\right.$; Falasco et al., 2013; Hofmann, 1994). Among the most common and abundant species there were also Gomphonema olivaceum (Hornemann) Brébisson, and Gomphonema parvulum (Kützing) Kützing. G. olivaceum is sensitive to organic pollution but can tolerate a moderate trophic load. Hence, it is generally abundant in the limestone streams with high conductivity (Falasco et al., 2013). G. parvulum, belonging to a complex of species with a large ecological value and a high tolerance to trophic and organic pollution, it is also widespread in sites affected by anthropogenic pressure due to urbanization and agriculture practices (Della Bella et al., 2007; Falasco et al., 2013).

Among the species found in more than half of the monitoring sites was Rhoicosphenia abbreviata (Agardh) Lange Bertalot, an epiphytic species which can be often found on aquatic macrophytes in brackish water and/or characterized by limestone substrates. It is characterized by a moderate tolerance to eutrophication (Della Bella et al., 2007). Both $N$. dissipata and $R$. abbreviata are characteristic species of sites with a surrounding land use of the catchment area devoted to agriculture that reflected in high values of nutrients in waters, as shown by studies carried out in other Italian regions (Bona et al., 2007; Della Bella et al., 2012). During the study, we also identified Reimeria uniseriata Sala Guerrero \& Ferrario, a diatom species that is considered an alien species in Italy (Falasco et al., 2013), and Diadesmis confervacea Kützing var. confervacea, a taxon considered non-native in Europe coming from tropical or subtropical areas (Coste and Ector, 2000). Both these species were found with low abundances $(<5.5 \%)$ and in only four samples belonging to $\mathrm{M} 1, \mathrm{M} 2$ and $\mathrm{M} 3$ river typologies.

The Indicator Species Analysis (ISA) suggested that in each river type some typical species occur (Tab. 3). For example, temporary rivers (M5) are characterized by $A$. minutissimum, which is a pioneer and mobile species, ca- pable of a fast river substratum recolonization after repeated annual dry phases. Plain large rivers (M3), instead, are characterized by slow water flow, which allows the development of planktonic species that can be also found in benthic communities, like Cyclotella meneghiniana Kützing.

According to the GLM analyses we found significant difference among macrotypes in terms of species richness $(\mathrm{df}=4$, deviance $=16.271, \mathrm{P}=0.003$; Fig. 3) and Shannon Index $(\mathrm{df}=4$, deviance $=2.523, \mathrm{P}=0.019$; Fig. 3). When we evaluated how species richness and Shannon Index were distributed across macrotypes (Fig. 3), we found that M4 and M5 showed a significant lower species richness. M5 showed also a significant lower value of the Shannon indexes (Tab. 4). By contrast, when we focussed on HERs (Fig. 3), we found that only the species richness was significant different between HER 11 and HER $13(\mathrm{df}=1$, deviance $=5.1931, \mathrm{P}=0.023)$ with the last showing a significant lower estimate of species richness values (Tab. 4).

Tab. 3. Characteristic species, defined by Indicator Species Analysis, for the five Mediterranean river macrotypes in analysis.

\begin{tabular}{l} 
River macrotype \\
Species \\
M1 - Small mid-altitude streams \\
Achnanthidium pyrenaicum (Hustedt) Kobayasi \\
Amphora inariensis Krammer \\
Encyonema silesiacum (Bleisch in Rabh.) D.G. Mann \\
M2 - Small and medium lowland streams \\
Cymatopleura solea (Brébisson) W. Smith \\
Gomphonema parvulum (Kützing) Kützing \\
Navicula tripunctata (Müller) Bory \\
M3 - Large lowland rivers \\
Cyclotella meneghiniana Kützing \\
Navicula capitatoradiata Germain \\
Navicula cincta (Ehrenberg) Ralfs \\
Navicula cryptocephala Kützing \\
Navicula cryptotenella Lange-Bertalot \\
Nitzschia frustulum (Kützing) Grunow \\
\hline M4 - Small and medium mountain streams \\
Denticula tenuis Kützing \\
Encyonema minutum (Hilse in Rabh.) D.G. Mann \\
Nitzschia fonticola Grunow \\
Nitzschia palea (Kützing) W. Smith \\
M5 - Small, lowland, temporary \\
Fragilaria recapitellata Lange-Bertalot \& Metzeltin \\
Gomphonema tergestinum Fricke \\
\end{tabular}


Tab. 4. Estimated richness and Shannon index coefficients. GLM results were reported for the three significant models. Estimates and their standard errors, $t$ or $\mathrm{z}$ test values and associate significance for each level of the fixed factors were reported.

\begin{tabular}{|c|c|c|c|c|}
\hline \multirow[b]{2}{*}{ Coeff. } & \multicolumn{4}{|c|}{ Macrotypes richness estimates } \\
\hline & Estimate & Std. Error & z value & $\operatorname{Pr}(>|z|)$ \\
\hline (Intercept) & 3.129 & 0.033 & 94.596 & $<0.001$ \\
\hline M2 & 0.017 & 0.054 & 0.323 & 0.747 \\
\hline M3 & 0.080 & 0.067 & 1.196 & 0.232 \\
\hline M4 & -0.281 & 0.125 & -2.252 & 0.024 \\
\hline M5 & -0.168 & 0.066 & -2.556 & 0.011 \\
\hline \multicolumn{5}{|c|}{ Macrotypes Shannon index estimates } \\
\hline Coeff. & Estimate & Std. Error & t value & $\operatorname{Pr}(>|z|)$ \\
\hline (Intercept) & 2.008 & 0.073 & 27.460 & $<0.001$ \\
\hline M2 & 0.032 & 0.119 & 0.268 & 0.79 \\
\hline M3 & 0.246 & 0.152 & 1.614 & 0.11 \\
\hline M4 & -0.271 & 0.243 & -1.117 & 0.28 \\
\hline M5 & -0.310 & 0.137 & -2.266 & 0.026 \\
\hline \multicolumn{5}{|c|}{ Hydro-ecological regions richness estimates } \\
\hline Coeff. & Estimate & Std. Error & $\mathrm{z}$ value & $\operatorname{Pr}(>|z|)$ \\
\hline (Intercept) & 3.143 & 0.026 & 122.888 & $<0.001$ \\
\hline HER 13 & -0.110 & 0.049 & -2.261 & 0.024 \\
\hline
\end{tabular}

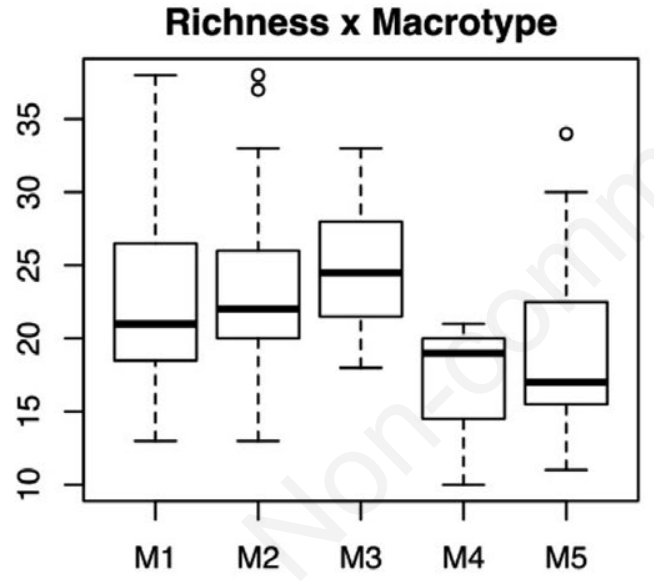

Richness x Hydroecoregions

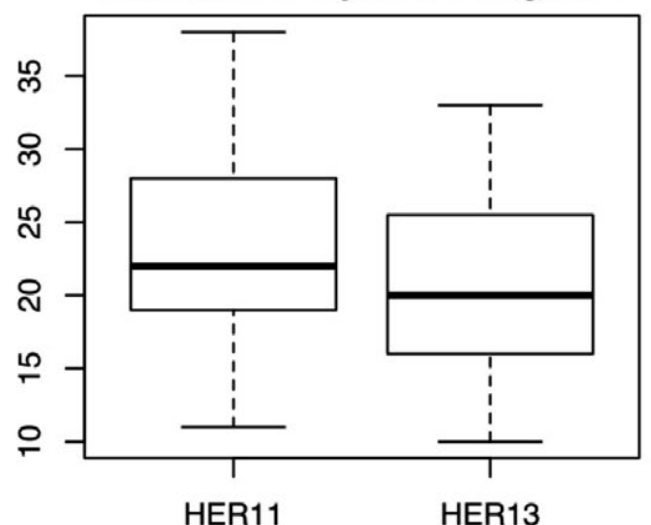

Shannon Index x Macrotype

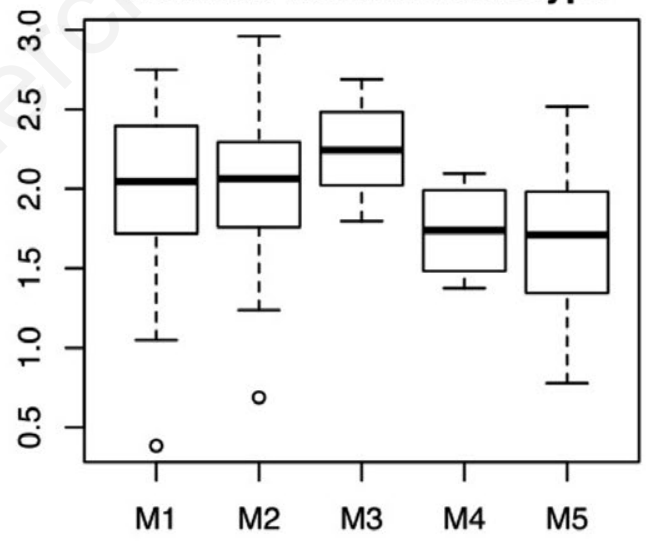

Shannon Index x Hydroecoregions

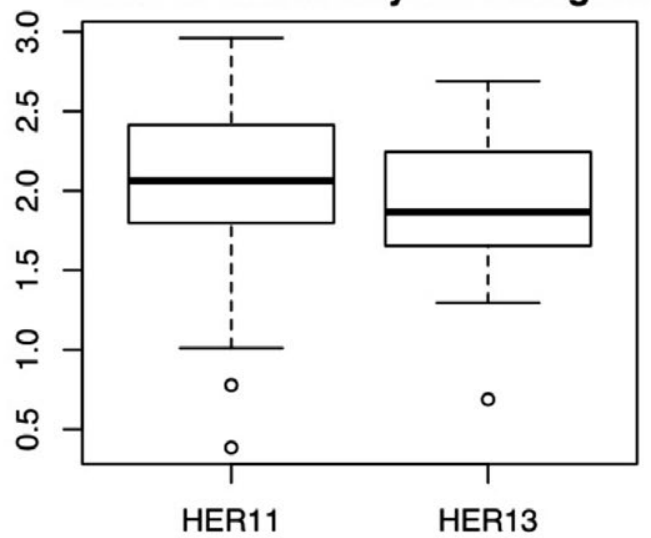

Fig. 3. Box plots of species richness and Shannon Index (on Y axis) among river macrotypes and among hydroecoregions (respectively, M and HER on $\mathrm{X}$ axis). The inner line is the median, the box margins are the $25^{\text {th }}$ and $75^{\text {th }}$ percentile, bars extend to $5^{\text {th }}$ and $95^{\text {th }}$ percentile. 
Intercalibration Common Metric Index (ICMi) classified $69 \%$ of water bodies in high or good class. Forty-two species (about $20 \%$ of the total) were not included in the list of taxa for the calculation of ICMi Index, because these diatom species were not included in the TI Index (Rott et al., 1999), as their sensitivity (TW) and reliability (G) values are still unknown.

We found a significant ICMi $(\mathrm{df}=4$, deviance $=0.67824, \mathrm{P}<0.001), \operatorname{IPS}(\mathrm{df}=4$, deviance $=55.867$, $\mathrm{P}<0.001)$ and $\mathrm{TI}(\mathrm{df}=4$, deviance $=3.8236, \mathrm{P}<0.001)$ variation among macrotypes (Fig. 4; Tab. 5). Particularly, the highest ICMi was found in M2 and M5, IPS was found to be significant lower in M2, M3 and M4 while M3 and M5 showed the lowest TI (Tab. 5). When we in- vestigated variation between HERs we found that only the TI was significant different $(\mathrm{df}=1$, deviance $=1.9075$, $\mathrm{P}=0.008$ ) with HER13 showing a significant lower value.

Finally, we did not find any significant correlation between species richness, Shannon Index and the three indexes when we took into account the total of 48 sites. However, when we limited the analysis to the 38 sites for which was possible to evaluate the ecological status on the basis of ICMi, we found that only the Shannon Index showed a significant negative correlation with the ICMi Index and IPS, while TI showed a significant positive correlation with both species richness and Shannon Index (Fig. 5).

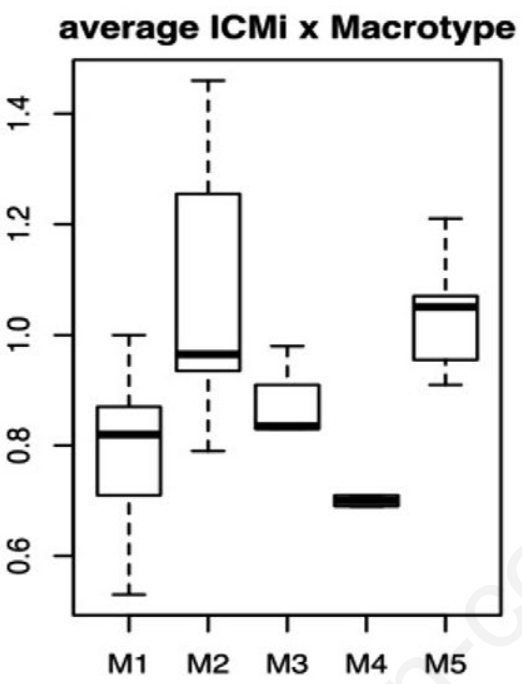

average ICMi x HER

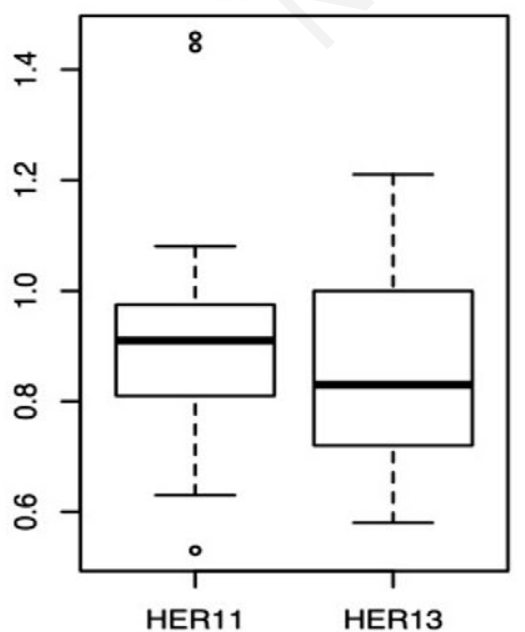

average IPS x Macrotype

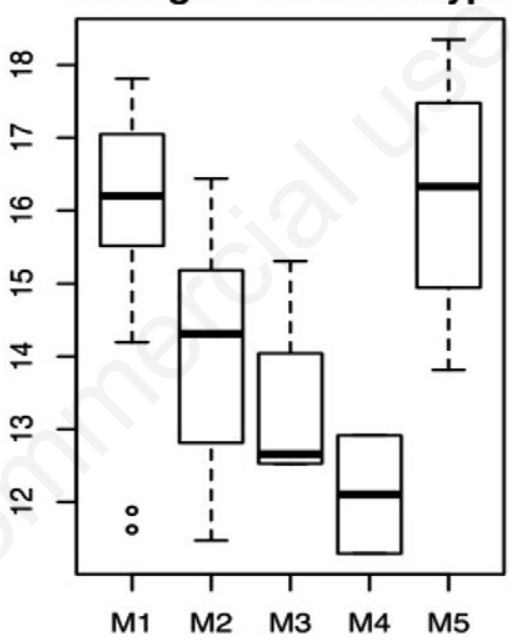

average IPS x HER

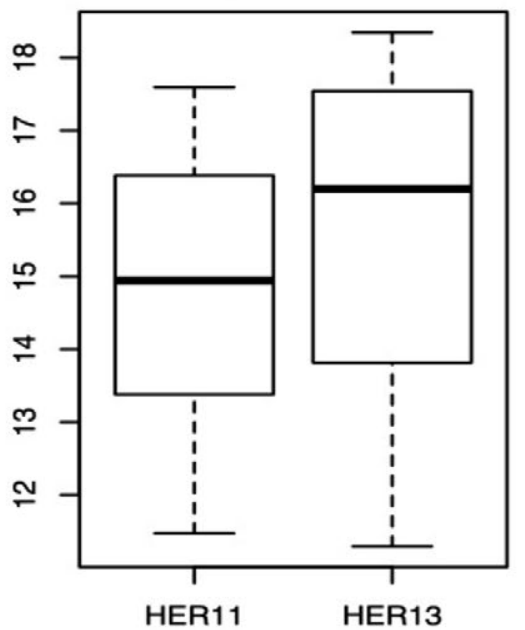

average TI x Macrotype

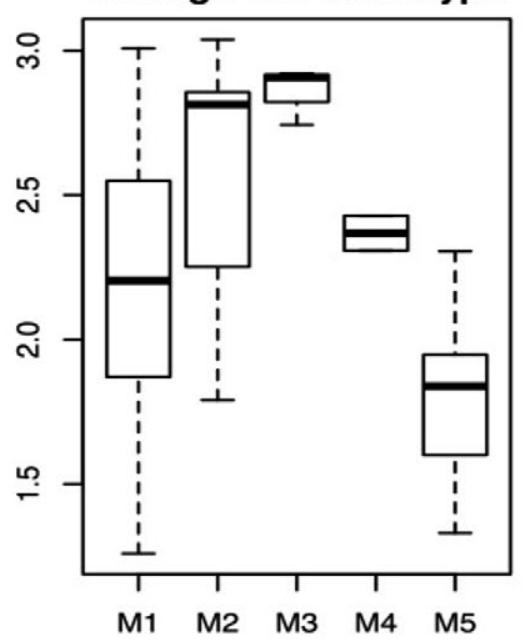

average TI x HER

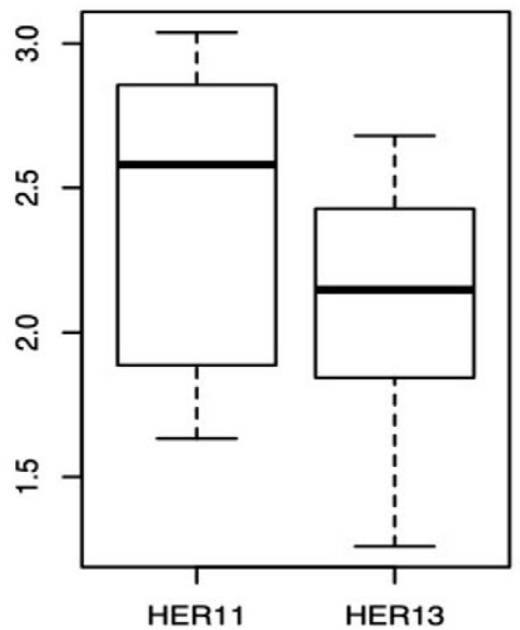

Fig. 4. Box plots of ICMi, IPS, TI values (Y axis) among macrotypes and among hydroecoregions (respectively, M and HER on X axis). The inner line is the median, the box margins are the $25^{\text {th }}$ and $75^{\text {th }}$ percentile, bars extend to $5^{\text {th }}$ and $95^{\text {th }}$ percentile. 
Tab. 5. Estimated values for the three indexes among macro-types and hydro-ecological regions.

\begin{tabular}{|c|c|c|c|c|}
\hline & \multicolumn{4}{|c|}{ Macrotypes ICMi estimates } \\
\hline & Estimate & Std. Error & t value & $\operatorname{Pr}(>|t|)$ \\
\hline (Intercept) & 0.777 & 0.037 & 20.885 & $<0.001$ \\
\hline M2 & 0.288 & 0.066 & 4.382 & $<0.001$ \\
\hline M3 & 0.089 & 0.085 & 1.049 & 0.302 \\
\hline M4 & -0.082 & 0.115 & -0.717 & 0.478 \\
\hline \multirow[t]{3}{*}{ M5 } & 0.253 & 0.069 & 3.671 & 0.001 \\
\hline & \multicolumn{4}{|c|}{ Macrotypes IPS estimates } \\
\hline & Estimate & Std. Error & $t$ value & $\operatorname{Pr}(>|t|)$ \\
\hline (Intercept) & 15.785 & 0.423 & 37.313 & $<0.001$ \\
\hline M2 & -1.720 & 0.748 & -2.300 & 0.028 \\
\hline M3 & -2.499 & 0.969 & -2.578 & 0.015 \\
\hline M4 & -3.682 & 1.304 & -2.824 & 0.008 \\
\hline \multirow[t]{3}{*}{ M5 } & 0.405 & 0.783 & 0.518 & 0.608 \\
\hline & \multicolumn{4}{|c|}{ Macrotypes TI estimates } \\
\hline & Estimate & Std. Error & t value & $\operatorname{Pr}(>|t|)$ \\
\hline (Intercept) & 2.225 & 0.101 & 22.137 & $<0.001$ \\
\hline M2 & 0.359 & 0.178 & 2.018 & 0.052 \\
\hline M3 & 0.644 & 0.230 & 2.798 & 0.009 \\
\hline M4 & 0.142 & 0.310 & 0.460 & 0.649 \\
\hline \multirow[t]{3}{*}{ M5 } & -0.429 & 0.186 & -2.306 & 0.028 \\
\hline & \multicolumn{4}{|c|}{ Hydro-ecological regions TI estimates } \\
\hline & Estimate & Std. Error & t value & $\operatorname{Pr}(>|t|)$ \\
\hline (Intercept) & 2.420 & 0.099 & 24.332 & $<0.001$ \\
\hline HER 13 & -0.367 & 0.168 & -2.188 & 0.035 \\
\hline
\end{tabular}

\section{CONCLUSIONS}

According to this result the diatom species richness did not result as a community variable related to the ecological quality of the studied river. A similar conclusion was already reported in previous works on other Italian (Della Bella et al, 2012) and European catchments (Blanco et al., 2012), and on other aquatic ecosystems (Cohen et al., 1993; Chipps et al., 2006; Della Bella and Mancini, 2009). Diatom diversity metrics exhibited poor linear correlations with environmental factors indicating ecological status because of complex environmental influences. The relationship between diatom diversity indices and productivity has remained unclear and then some authors suggested that these indices are not suitable for evaluating ecological conditions (Blanco et al., 2012). Archibald (1972) found linear negative and Lavoie et al. (2008) found positive relationships between diversity and nutrients. Soininen (2009) indicated that other variables than nutrients determine diatom diversity. For example, Stenger-Kovács et al. (2014) found that stream order is a relevant typological parameter which can basically influence the diatom species number and diversity. Species richness and diversity indices, like the Shannon Index, are two important aspects of diversity, but it is not obvious that both respond in a similar way to varying intensities of disturbance (Svensson et al., 2012). Indices of diversity generally include both the number of species and their relative abundances, which make assessment of their responses more complex. Diversity indices based on species relative abundances (e.g., Shannon Index) could show misleading responses and could be unsuitable for comparison of biological communities. A recent study on other biological community showed that the majority of the biodiversity metrics increased whereas the most abundant species declined and highlighted that increasing metrics of diversity may occur in parallel with substantial losses of individuals (Schipper et al., 2016).

The present study highlighted differences in diversity metrics (species richness and Shannon Index) of diatom communities in Mediterranean river types, and this finding suggested that this aspect should be taken into account when comparison studies were made among different river typologies. Although our analyses could be affected by an imbalance in the number of observations among macrotypes and further testing with additional data of different hydroecoregion are necessary, our results indicated 

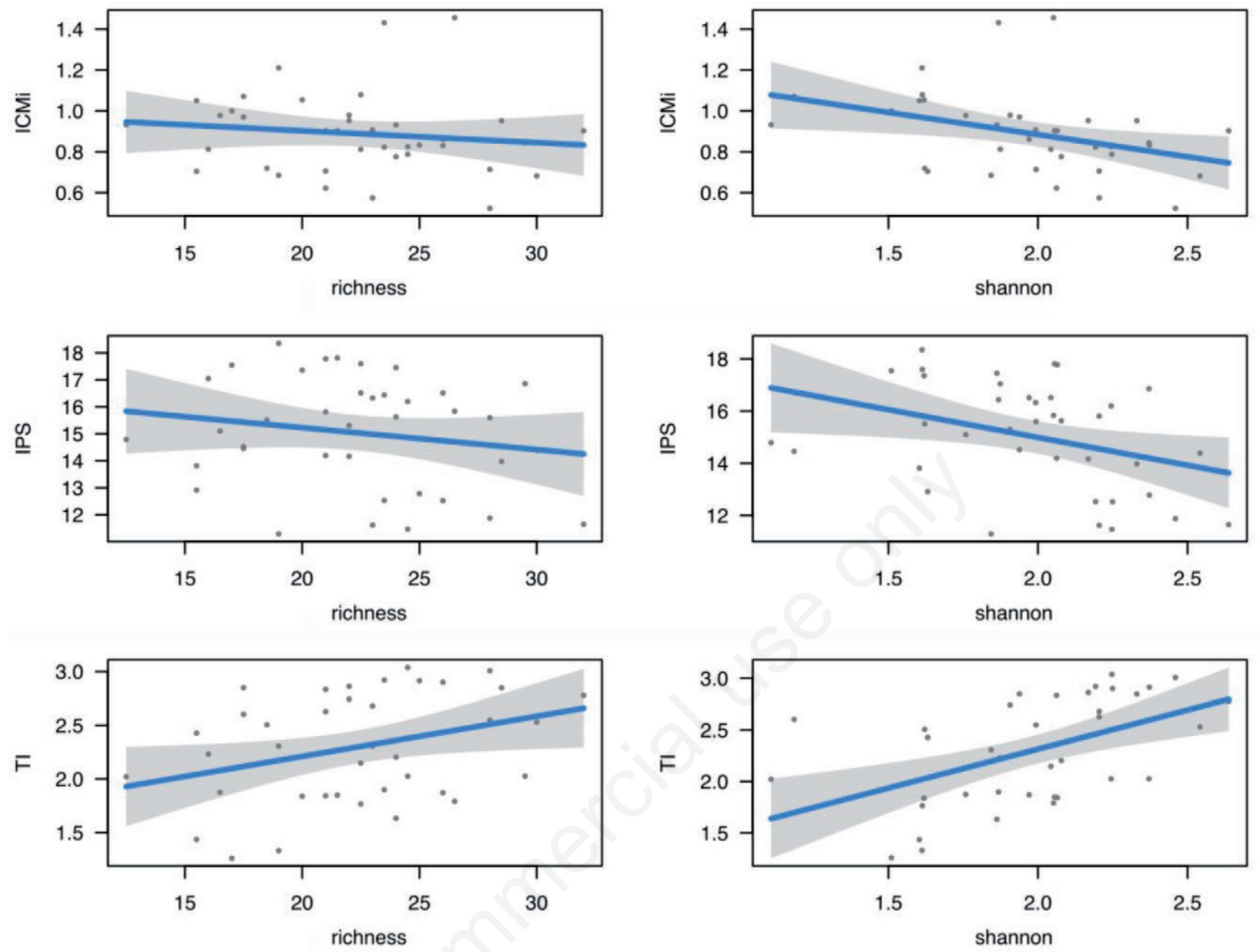

Fig. 5. Predicted values (blue continuous line) and confidence intervals ( $95 \%$, light grey area) for species richness and Shannon Index of diatoms in relation to the ICMi, IPS and TI index values.

that the diatom diversity metrics could be considered complementary parameters in river biomonitoring for the ecological status assessment based on diatoms.

\section{ACKNOWLEDGMENTS}

We thank to E. Rinaldi, M. Di Brizio, S. Bracchi, L. Galli, I. Crescentini, and M.C. Bocale for their valuable work in sampling and laboratory analyses. Thanks to Rossano Bolpagni for editing care and to an anonymous referee for suggestions that improved the first version of the manuscript.

\section{REFERENCES}

APAT, 2007. [Protocollo di campionamento e analisi delle diatomee bentoniche dei corsi d'acqua]. In: APAT (ed.),
[Metodi Biologici per le acque dolci. Parte I].[in Italian]. Manuali e Linee Guida XX/2007. Available from: http:// www.isprambiente.gov.it/it/pubblicazioni/manuali-e-lineeguida/metodi-biologici-per-le-acque-parte-i

Archibald REM, 1972. Diversity and some South African diatom association and its relation to water quality. Water Res. 6:1229-1238.

ARPA Umbria, 2008. [Definizione della rete di monitoraggio dei corpi idrici superficiali della regione Umbria ai sensi della Direttiva 2000/60/CE (DLgs 152/06 e s.m.i.)].[in Italian]. ARPA Umbria, Perugia, Italy. Available from: http:// http://www.arpa.umbria.it/pagine/acque-superficiali

Battegazzore M, Gallo L, Lucadamo L, Morisi A, 2003. Quality of the main watercourses in the Pollino National Park (Appennine Mts, S Italy) on the basis of diatom benthic communities. Studi Trent. Sc. Nat. Acta Biol. 80:89-93.

Battegazzore M, Morisi A, Gallino B, Fenoglio S, 2004. Environmental quality evaluation of Alpine springs in NW Italy using benthic diatoms. Diatom Res. 19:149-165.

Beltrami ME, Ector L, Ciutti F, Cappelletti C, Hoffmann L, Rott 
E, 2009. Longitudinal variations of benthic diatoms and water quality along a large river (Adige River) in Northern Italy. Verh. Internat. Verein. Theor. Angew. Limnol. 30:915-918.

Blanco S, Cehudo-Figuerias C, Tudesque L, Bécares E, Hoffmann L, Ector L, 2012. Are diatom diversity indices reliable monitoring metrics? Hydrobiologia 695:199-206.

Bona F, Falasco E, Fassina S, Griselli B, Badino G, 2007. Characterization of diatom assemblages in mid-altitude streams of NW Italy. Hydrobiologia 583:265-274.

Cantonati M, Pipp E, 2000. Longitudinal and seasonal differentiation of epilithic diatom communities in the uppermost sections of two mountain spring-fed streams. Verh. Internat. Verein. Theor. Angew. Limnol. 27:1591-1595.

Cappelletti C, Ciutti F, Crippa A, Mancini L, Beltrami ME, Pierdominici E, Dell'Uomo A, 2005. [Diatomee come indicatori della qualità biologica dei corsi d'acqua. EPI-D ed altri metodi europei a confronto: il caso di studio del fiume Tevere].[Article in Italian]. Biol. Amb. 19:103-108.

CEMAGREF, 1982. [Etude des methodes biologiques quantitative d'appreciation de la qualité des eaux].[Book in French]. Rapport Q.E. A.F. Bassin Rhone-Mediterranee-Corse, Lyon: $218 \mathrm{pp}$.

Chipps ST, Hubbard DE, Werlin KB, Haugerud NJ, Powell KA, Thompson J, 2006. Association between wetland disturbance and biological attributes in floodplain wetlands. Wetlands 26:497-508.

Cohen AS, Bills R, Cocquyt CZ, Caljon AG, 1993. The impact of sediment pollution on biodiversity in Lake Tanganyika. Conserv. Biol. 7:667-677.

Coste M, Ector L, 2000. [Diatomees invasives exotiques ou rares en France: principales observations effectuees au cours des dernieres decennies].[Article in French]. Syst. Geogr. P1. 70:373-400.

Ciutti F, Della Bella V, Beltrami ME, Puccinelli C, Marcheggiani S, Cappelletti C, Martinelli A, Mancini L, 2007. [Le comunità diatomiche del bacino del fiume Tevere: uno studio pilota]. Proceedings 27th Congr. SITE-AIOL "Ecologia, Limnologia e Oceanografia: quale futuro per l'ambiente?" [Article in Italian]. Ancona, Italy.

Dell'Uomo A, 1999. Use of algae for monitoring rivers in Italy: current situation and perspectives, p. 17-25. In: J. Prygiel, B.A. Whitton and J. Bukowska (eds.), Use of algae for monitoring rivers III. Agence de 1'Eau Artois-Picardie, Douai.

Della Bella V, Mancini L, 2009. Freshwater diatom and macroinvertebrate diversity of coastal permanent ponds along a gradient of human impact in a Mediterranean ecoregion. Hydrobiologia 634:25-41.

Della Bella V, Marcheggiani S, Puccinelli C, Mancini L, 2007. Benthic diatom communities and their relationship to water variables in wetlands of central Italy. Ann. Limnol.-Int. J. Lim. 43:89-99.

Della Bella V, Pace G, Barile M, Zedde A, Puccinelli C, Ciadamidaro S, Danieli PP, Andreani P, Aulicino FA, Belfiore C, Mancini L, 2012. Benthic diatom assemblages and their response to human stress in small-sized volcanicsiliceous streams of central Italy (Mediterranean eco-region). Hydrobiologia 695:207-222.

Dufrêne M, Legendre P, 1997. Species assemblages and indicator species: the need for a flexible asymmetrical approach. Ecol. Monogr. 67:345-366.
European Commission, 2000. Directive 2000/60/EC of the European Parliament and of the Council of 23 October 2000 establishing a framework for Community action in the field of water policy. OJ L 327, 22/12/2000, p. 1-73.

European Commission, 2008. Commission decision of 30 October 2008 establishing, pursuant to Directive 2000/60/ EC of the European Parliament and of the Council, the values of the Member State monitoring system classifications as a result of the intercalibration exercise. OJ L 332, 10/12/2008, p. 20-44.

European Committee for Standardization, 2003. European Standard EN 13946. Water quality - Guidance standard for the routine sampling and pretreatment of benthic diatoms from rivers. CEN, Brussels: 14 pp.

European Committee for Standardization, 2004. European Standard EN 14407. Water quality - Guidance standard for the identification, enumeration and interpretation of benthic diatom samples from running waters. CEN, Brussels: $12 \mathrm{pp}$.

Falasco E, Bona F, 2013. Recent findings regarding non-native or poorly known diatom taxa in north-western Italian rivers. J. Limnol. 72:35-51.

Falasco E, Mobili L, Risso AM, Bona F, 2012. [Considerazioni sull'applicazione dell'indice diatomico ICMi (Intercalibration Common Metric index) nell'Italia nord-occidentale].[Article in Italian]. Biol. Amb. 26:1-8.

Falasco E, Piano E, Bona F, 2013. [Guida al riconoscimento e all'ecologia delle principali diatomee fluviali dell'Italia Nord Occidentale].[Article in Italian]. Biol. Amb. 27:1-277.

Finocchiaro M, Torrisi M, Ferlito A, Dell'Uomo A, Ector L, 2011. [Biodiversità algale in Sicilia: diatomee rare o notevoli del bacino idrografico del fiume Simeto].[Article in Italian]. Biogeographia 30:13-29.

Hofmann VG, 1994. [Aufwuchs Diatomeen in Seen und ihre Eignung als Indikatoren der Trophie].[Article in German]. Biblioth. Diatomol. 30: 1-241.

Hofmann VG, Werum M, Lange-Bertalot H, 2011. Diatomeen im Süßwasser - Benthos von Mitteleuropa].[Book in German]. A.R.G. Gantner Verlag, Vaduz: 908 pp.

Italian Regulation, 2006. [Norme in materia ambientale].[in Italian]. Legislative Decree No. 152, 3 April 2006. Ordinary Supplement No. 96 to the OJ No. 88, 04/04/2006.

Italian Regulation, 2008. [Regolamento recante i criteri tecnici per la caratterizzazione dei corpi idrici (tipizzazione, individuazione dei corpi idrici, analisi delle pressioni) per la modifica delle norme tecniche del decreto legislativo 3 aprile 2006 , n. 152 , recante norme in materia ambientale, predisposto ai sensi dell'articolo 75, comma 4, dello stesso decreto].[in Italian]. Ministry Decree No. 131/2008. Ordinary Supplement No. 189 to the Official Journal No. 187, $11 / 08 / 2008$.

Italian Regulation, 2010. [Regolamento recante i criteri tecnici per la classificazione dello stato dei corpi idrici superficiali, per la modifica delle norme tecniche del decreto legislativo 3 aprile 2006, n. 152, recante norme in materia ambientale, predisposto ai sensi dell'articolo 75, comma 3, del medesimo decreto legislativo].[in Italian]. Ministry Decree No. 260/2010. Ordinary Supplement No. 31 to the Official Journal No. 30, 07/02/2011.

Kelly MG, Cazaubon A, Coring E, Dell'Uomo A, Ector L, Gold- 
smith B, Guasch H, Hurlimann J, Jarlman A, Kawecka B, Kwandrans J, Laugaste R, Lindstrom EA, Leitao M, Marvan P, Padisàk J, Pipp E, Prygiel J, Rott E, Sabater S, van Dam H, Vizinet J, 1998. Recommendations for the routine sampling of diatoms for water quality assessments in Europe. J. Appl. Phycol. 10:215-224.

Krammer K, 2000. The genus Pinnularia. A.R.G. Gantner Verlag K.G., Vaduz: 703 pp.

Krammer K, Lange-Bertalot H, 1986. [Bacillariophyceae 1 Teil: Naviculaceae].[Book in German]. Gustav Fischer Verlag, Stuttgart: $876 \mathrm{pp}$.

Krammer K, Lange-Bertalot H, 1988. [Bacillariophyceae 2 Teil: Bacillariaceae, Epithemiaceae, Surirellaceae].[Book in German]. Gustav Fischer Verlag, Stuttgart: 596 pp.

Krammer K, Lange-Bertalot H, 1991a. [Bacillariophyceae 3 Teil: Centrales, Fragilariaceae, Eunotiaceae].[Book in German]. Gustav Fischer Verlag, Stuttgart: 576 pp.

Krammer K, Lange-Bertalot H, 1991b. [Bacillariophyceae 4 Teil: Achnanthaceae. Kritische Ergänzungen zu Navicula (Lineolatae) und Gomphonema].[Book in German]. Gustav Fischer Verlag, Stuttgart: 437 pp.

Krammer K, Lange-Bertalot H, 2000. [Bacillariophyceae 5 Teil: English and French translation of the keys].[German and French edition]. Gustav Fischer Verlag, Stuttgart: 311 pp.

Lange-Bertalot H, 2001. Navicula sensu stricto. 10 genera separated from Navicula sensu lato. Frustulia. A.R.G. Gantner Verlag K.G., Vaduz: 526 pp.

Lavoie I, Campeau S, Darchambeau F, Cabana G, Dillon J, 2008. Are diatoms good integrators of temporal variability in stream water quality? Freshwater Biol. 53:827-841.

Mancini L, Puccinelli C, Della Bella V, Marcheggiani S, Beltrami ME, Cappelletti C, Ciutti F, 2008. Freshwater diatoms of the Tiber River basin (Central Italy). In: Proceedings of "Central European Diatom Meeting" (CEDIATOM2), Trentino Nature \& Science Museum, Trento, Italy.

Mancini L, Sollazzo C, 2009. [Metodo per la valutazione dello stato ecologico delle acque correnti: comunità diatomiche].[Report in Italian]. Rapporti ISTISAN 09/19. Istituto Superiore di Sanità, Rome: 32 pp.

Prygiel J, Coste M, Bukowska J, 1999. Review of the major diatom-based techniques for the quality assessment of rivers. State of art in Europe, p. 122-127. In: J. Prygiel, B.A. Whitton and J. Bukowska (eds.), Use of algae for monitoring rivers III. Agence de l'Eau Artois-Picardie, Douai.

R Core Team, 2015. R: A language and environment for statistical computing. R Foundation for Statistical Computing, Vienna, Austria. Available from: https://www.R-project.org/
Rott E, Pfister P, van Dam H, Pipp E, Pall K, Binder N, Ortler K, 1999. [Indikationslisten fur Aufwuchsalgen. Teil 2: Trophieindikation sowie geochemische Praferenz, taxonomische und toxikologische Anmerkungen].[Report in German]. Bundesministerium fur Land und Forstwirtschaft, Wien: 248 pp.

Rott E, Cantonati M, Fureder L, Pfister P, 2006. Benthic algae in high altitude streams of the Alps - a neglected component of the aquatic biota. Hydrobiologia 562:195-216.

Schipper AM, Belmaker J, Dantas de Miranda M, Navarro LM, Böhning-Gaese K, Costello MJ, Dornelas M, Foppen R, Hortal J, Huijbregts MAJ, Martín-López B, Pettorelli N, Queiroz C, Rossberg AJ, Santini L, Schiffers K, Steinmann ZJN, Visconti P, Rondinini C, Pereira HM, 2016. Contrasting changes in the abundance and diversity of North American bird assemblages from 1971 to 2010 . Glob. Change Biol. 22:3948-3959.

Scuri S, Torrisi M, Cocchioni M, Dell'Uomo A, 2006. The European Water Framework Directive 2000/60/EC in the evaluation of the ecological status of watercourses. Case study: The River Chienti (central Apennines, Italy). Acta Hydroch. Hydrob. 34:498-505.

Soininen J, 2009. Is diatom diversity driven by productivity in boreal streams? Diatom Res. 24:197-207.

Stenger-Kovács C, Tóth L, Tóth F, Hajnal É, Padisák J, 2014. Stream order-dependent diversity metrics of epilithic diatom assemblages. Hydrobiologia 721:67-75.

Svensson JR, Lindegarth M, Jonsson PR, Pavia H, 2012. Disturbance-diversity models: what do they really predict and how are they tested? P. Roy. Soc. B-Biol. Sci. 279:21632170.

Torrisi M, Dell'Uomo A, Ector L, 2008. [Evaluation de la qualité des rivières des Apennins (Italie) au moyen des indices diatomiques: le fleuve Foglia].[Article in French] Cryptogam. Algol. 29:45-61.

Torrisi M, Scuri S, Dell'Uomo A, Cocchioni M, 2010. Comparative monitoring by means of diatoms, macroinvertebrates and chemical parameters of an Apennine watercourse of central Italy: The river Tenna. Ecol. Indic. 10:910-913.

Wasson JW, Garcia Bautista A, Chandesris A, Pella H, Armanini D, Buffagni A, 2006. [Approccio delle Idro-Ecoregioni Europee e tipologia fluviale in Francia per la Direttiva Quadro sulle Acque (2000/60/EC)].[Report in Italian]. IRSA-CNR Notiziario dei Metodi Analitici 1:39-64.

Zorza R, Honsell G, 2008. [Studio sulle diatomee bentoniche del fiume Natisone (Italia nord-orientale)].[Article in Italian]. Gortania 30:73-88. 